\title{
Potential use of byproducts from cultivation and processing of sweet potatoes
}

\author{
Winifred Akoetey ${ }^{1}$ Margaret Mead Britain ${ }^{1}$ Ruben Omar Morawicki ${ }^{*}$ \\ ${ }^{1}$ Food Science Department, University of Arkansas, 2650, N Young, 72704, Av. Fayetteville, Arkansas. E-mail: rmorawic@uark.edu. \\ ${ }^{*}$ Corresponding author.
}

ABSTRACT: The cultivation and processing of sweet potatoes into a variety of products yields both solid and liquid organic waste. Solid waste includes peelings and trimmings from the sweet potato root and sweet potato leaves and vines. Liquid waste results from various processing methods and creates significant amounts of nutrient rich waste water. Sweet potato waste materials contain carbohydrates, proteins, phenolic compounds, macro and micro nutrients, and pigments that have the potential of being extracted or utilized for various downstream processes and products. This review examines many of the different ways that these waste products can be utilized. Key words: sweet potato, byproduct, food processing, starch, fermentation.

Potencial para utilização de subprodutos do cultivo e processamento de batata-doce

RESUMO: O cultivo e processamento de batata doce gera uma variedade de produtos e também resíduos orgânico solido e liquido. Resíduos sólidos incluem casca e pedaços da raiz de batata doce, alem de folhas e ramas. Resíduo liquido resulta de vários métodos de processamento, gerando uma quantidade significativa de água residual rica em nutrientes. Resíduos de batata doce contem carboidratos, proteínas, compostos fenólicos, macro e micro nutrientes, e pigmentos que tem o potencial de ser extraídos ou utilizados para diversos processos e produtos. Esta revisão examina muitas das diferentes formas de aproveitar estes resíduos.

Palavras-chave: batata-doce, subproduto, processamento de alimentos, o amido, a fermentação.

\section{INTRODUCTION}

Sweet potato is one of the most widely grown food crops in the world. It is cultivated in about 111 countries with a total of 110.75 million tons produced in 2013. China alone accounts for about $71 \%$ of the production. The global amount of sweet potato waste in 2011 accounted for about $7 \%$ of the entire crop (FAO, 2016).

Sweet potato is a root tuber which is rich in carbohydrates and minerals and has a high moisture content. On dry basis, sweet potato contains $80-90 \%$ carbohydrate, of which $60-70 \%$ is starch. However, the ratio of starch to other carbohydrates such as sugars and the general relative composition of the root tuber vary with cultivar, maturity, and storage time (WOOLFE, 1992). Other useful components present in sweet potatoes include proteins, vitamins, carotenoids, polyphenols, and minerals. Sweet potato high carbohydrate content has established it as an energy dense staple food in many countries (WOOLFE, 1992; SUN et al., 2014). The processing of the root tuber into starch, alcoholic beverages, ethanol, flour, purees, and other commodities generates byproducts that currently have very little utilization and normally add to the waste going into landfills and bodies of water.

Another important byproducts of sweet potato production are vines and leaves that come from the agricultural phase. Vines and leaves are a good source of protein, vitamins, minerals, pigments, and polyphenols. However, with exception of small scale farms that use this byproduct to feed farm animals, vines and leaves have very little application.

This paper is a review of the sweet potato literature up to the year 2015, focusing on the waste that is generated from processing/cultivation and on the potential utilization of these byproducts. For this purpose, the following databases were used: SciFinder, Web of Science, and Google Scholar.

\section{Sweet potato processing}

According to the FAO food balance sheets for 2011, of the total sweet potato supply in the world (102,530 thousand metric tons), an estimated 53\% was utilized as food or seed, $40 \%$ as feed, and about $7 \%$ was waste. Data from the following countries emphasizes this diversity in utilization. Uganda used about $85 \%$ of its sweet potato production as food, and almost none as feed. China used about $51 \%$ as feed 
and $44 \%$ as food. The United States used about $95 \%$ as food and $3.6 \%$ as feed (FAO, 2016).

Commercial processing of sweet potato products depends on the market and the location. For example, in China, about $15-20 \%$ of sweet potato production in some provinces is processed into starch. The starch, in turn, is used as feedstock to produce glucose syrups, noodles, and organic acids, or utilized in the textile industry. Other processing methods include the manufacture of dried sweet potato chips, which can be milled into flour for incorporation into other food products. Canning and freezing is another major form of processing that takes place in countries with a robust food processing infrastructure like the United States.

The processing of sweet potatoes results in a variety of byproducts depending on the processing method and desired product. Starting at the farm level, waste is generated from the removal of the vines and leaves and also from the tubers that do not meet size grading requirements or are damaged due to harvesting techniques. During processing, the byproducts generated are in the form of peels, trimmings, chunks of tuber, and nutrient-rich waste water (WOOLFE, 1992).

Wastewater from starch production is a major environmental concern, especially in China and Japan. During the initial stages of starch production, about $6 \mathrm{~m}^{3}$ of water is used per ton of sweet potato tuber. Disposal of this water is problematic in that it has a high chemical oxygen demand (XU et al., 2014). The peeling process during canning operations, in which almost half the raw material becomes waste, also generates large amounts of waste water with a high biological oxygen demand (WOOLFE, 1992). The byproducts resulting from processing are rich in carbohydrates, protein, anthocyanins, and vitamins that could be used as feedstocks for the manufacturing of value-added products (ISLAM et al. 2002).

\section{Potential use of leaves and vines}

Although sweet potato leaves and vines can be cooked and eaten and are very nutritious, they are generally discarded, particularly in North America. SUN et al. (2014) examined sweet potato leaves from 40 sweet potato varieties, analyzing, among other things, crude protein, fiber, fat, carbohydrates, gross energy, ash, macro and micro nutrients, total polyphenols, and antioxidant activity. They reported that leaf protein content was 16.69 to $31.08 \mathrm{~g} 100 \mathrm{~g}^{-1} \mathrm{~d}$.w. (dry weight), crude fiber ranged from 9.15 to $14.26 \mathrm{~g}$

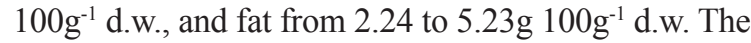
amounts of the micronutrients $\mathrm{Ca}, \mathrm{K}, \mathrm{P}, \mathrm{Mg}, \mathrm{Na}, \mathrm{Fe}$,
$\mathrm{Mn}, \mathrm{Zn}$, and $\mathrm{Cu}$ were also judged to be significant and varied considerably from cultivar to cultivar. The most abundant microelement was K (1625.1 mg $100 \mathrm{~g}^{-1}$ d.w.) although $\mathrm{Fe}, \mathrm{Mn}, \mathrm{Zn}$, and $\mathrm{Cu}$ were also abundant.

Bioactive phenolic compounds were determined to be the most important antioxidants in sweet potato leaves. SUN et al. (2014) determined that the leaves of sweet potatoes contained considerable amounts of the phenolic compounds 5-O-caffeoylquinic acid, 3-O-caffeoylquinic acid, 4-O-caffeoylquinic acid, caffeic acid, 4,5-di-O-caffeoylquinic acid, 3,5-diO-caffeoylquinic acid, 3,4-di-O-caffeoylquinic acid, and 3,4,5-tri-O-caffeoylquinic acid. The same authors also reported a total level of polyphenol of $12.46 \mathrm{~g}$ $100 \mathrm{~g}^{-1}$ d.b. based on the Folin-Ciocalteu method using chlorogenic acid as standard, which correlates with antioxidant activities of $1.28 \pm 0.07 \mu \mathrm{g}$ Trolox equiv/mg, d.b. based on the ORAC method.

A report by TRUONG et al. (2007) displayed an average polyphenol content of $1248.8 \mathrm{mg}$ chlorogenic acid $100 \mathrm{~g}^{-1}$ fresh weight (f.w.) in the leaves, while exhibiting only $20.27 \mathrm{mg}$ chlorogenic acid $100 \mathrm{~g}^{-1}$ f.w. in the cooked roots. Using the same comparison, antioxidant activity was $38.1 \mathrm{mM}$ Trolox $\mathrm{g}^{-1}$ f.w. for the leaves and $3.0 \mathrm{mM}^{\text {Trolox }} \mathrm{g}^{-1}$ f.w. for the cooked roots. In comparison to traditional vegetables, sweet potato leaves contain concentrations of polyphenols comparable to spinach and broccoli.

Additionally, HUANG et al. (2010b) reported that a water extract of sweet potato leaves inhibited nitric oxide production in macrophages and also protected mouse liposomes against oxidative damage. Lyophilized powder prepared from sweet potato leaves suppressed the growth of both Escherichia coli and Bacillus bacteria. However, the anti-bacterial effect did not suppress bifidobacteria that are useful for human health (ISLAM et al., 2004).

The lutein content $\left(31.5-42.6 \mathrm{mg}^{100 \mathrm{~g}^{-1}}\right.$ f.w.) of the Suioh variety of sweet potatoes exceeded the content of lutein of 120 other fruits and vegetables (ISHIGURO \& YOSHIMOTO, 2006). Lutein is a nonprovitamin A yellow-to-orange color carotenoid that plays an important role in the human retina by protecting the macula from damaging blue wavelengths and by scavenging reactive oxygen species (LANDRUM \& BONE, 2001). Therefore, sweet potato leaves deserve consideration as a desirable food for the prevention of eye diseases (MENELAOU et al., 2006; ISHIGURO \& YOSHIMOTO, 2006). Additionally, lutein contained in sweet potato leaves could be potentially used as a replacement for tartrazine (FD\&C Yellow 5). HUE et al. (2014) isolated and purified the yellow fraction of sweet potatoes by extracting ground leaves with three 
types of solvents (acetone, methanol, tetrahydrofuran, and petroleum ether: tetrahydrofuran mixture (4:1)). After extraction, the solvents were removed by roto-evaporation and the residue saponified with variable concentrations of potassium hydroxide and durations. Saponification is an important step to remove chlorophyll pigments. Once the saponification was completed, the pigments were extracted with acetone and analyzed by liquid chromatography mass spectroscopy. Of all the solvents used, acetone was the most effective at removing a mixture of $\beta$-carotene and lutein. The final amount of $\beta$-carotene and lutein were

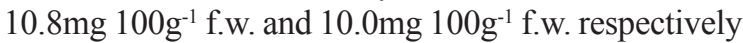
(HUE et al., 2014). To put this in perspective, the $\beta$-carotene content in pumpkin (Curcubita minima) is $1.16 \mathrm{mg}^{100 \mathrm{~g}^{-1}} \mathrm{f}$. and in mango (Mangifera indica)

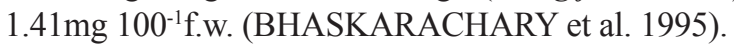

Crude protein in sweet potato leaves ranges between $25.5-29.8 \%$ in dry matter (AN et al., 2003). Even when a significant protein content, sweet potato leaves does not contain a complete amino acid profile. One of the shortcomings is the deficiency of lysine. ISHIDA et al. (2000) reported the amino acid quality of two varieties of sweet potato scored at 76.1 and 83.9, which was also verified by AN et al (2003).

Research has been conducted on the use of leaves and vines as animal feed. In a research comparing utilization efficiency of sweet potato leaves with Lucerne meal, chickens showed no difference in growth rate, food intake or conversion when fed up to $160 \mathrm{~g} \mathrm{~kg}^{-1}$ sweet potato leaves versus Lucerne meal (FARRELL et al., 2000). Combined with Batiki grass (Ischaemum aristatum var. indicum), a low nutrient forage crop, sweet potato vines supported higher weight gains in goats than either the Batiki grass or the sweet potato vines alone (AREGHEORE, 2004). When supplemented with an energy-protein concentrate, sweet potato vines supported goat meat production and was reported to be particularly useful when feed was scarce (KATONGOLE et al., 2009). I leal and total tract digestibility studies on growing pigs indicated that sweet potato leaves can improve dietary protein and amino acid supply in pigs fed with a low fiber diet (AN et al., 2003). A recent research on pigs, which compared ileal digestibility of amino acids using a diet comprised of $25 \%$ fresh sweet potato leaves versus a control diet with casein as the only protein source, concluded that sweet potato leaves could only replace a fraction of the protein typically derived from a more expensive plant-based source, such as soybeans, because of high fiber content and the presence of compounds that decreased amino acid digestibility. However, sweet potato leaves are still potentially quite useful as a protein-supplement for pigs in the tropics where there is a close association between local feed sources, local crops, and animals-small-scale, mixed-farming systems (REGNIER et al., 2012; REGNIER et al., 2013). Nguyen reported that ensiling the leaves resulted in a higher digestibility of nutrients compared to drying the leaves (NGUYEN et al., 2012).

Sweet potato leaves can also be used to support small-scale aquaculture, even though the phytic acid content $(3.29 \%)$ is considered high for fish growth (DONGMEZA et al., 2009). Other antinutritional compounds reported in sweet potato leaves are tannic acid and oxalic acid at

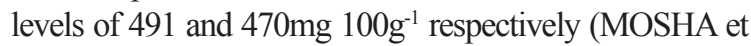
al., 1995). Dairy heifers exclusively fed with Sweet potato leaves were compared favorably with exclusive Lucerne and napier grass feeding. Crude protein, $\mathrm{Ca}$, and $\mathrm{P}$ levels were reported to be sufficient to sustain heifer growth (KARIUKI et al., 1998). In a rice/sweet potato cropping system, cattle fed with sweet potato leaves produced more manure than the control cattle. Manure was then used as fertilizer for rice production (OKE \& WORKNEH, 2013).

\section{Utilization of sweet potato peels and culled sub- optimal roots}

Sweet potato peels produced from industrial processes are responsible for an enormous amount of waste. It has been estimated that approximately $30 \%$ of the raw material coming into sweet potato canning operations is discarded and not used for human consumption (SCHAUB \& LEONARD, 1996). If they are used at all, the peels are typically used for either fertilizer or animal food. However, given regional shortages, it is perhaps the protein content that deserves the most attention. The total protein content of sweet potato is about $5 \%$ of the dry weight, and the predominant soluble protein is sporamin. Research indicates that the protein present in the tuber is not evenly distributed and that higher concentrations are found in the outer layer of the flesh close to the peel. Depending on the method of peeling, $4.4 \%-12 \%$ of the protein content of the tuber may be removed in preparation for further processing (WALTER et al., 1984).

Sweet potato protein exhibits good solubility and emulsifying properties and thus is a candidate as a functional ingredient in processed food applications (WOOLFE, 1992). MALONEY et al. (2012) examined the protein content of sweet potato peels produced at two points in the processing of sweet potato puree. Initial peeling of the sweet potato yielded the primary peels. Secondary peels were produced after the potatoes were blanched, and then 
peeled a second time. Protein was reported to be more easily extracted from the secondary peels. About $32 \%$ of protein in the peels was recovered from a process optimized using saline and calcium chloride.

In subsistence aquaculture systems, sweet potato peels may have some use as fish food. OMOREGIE et al. (2009) reported that fish fed with sweet potato peels exhibited depressed growth when compared to a control diet (no sweet potato peels). However, when the peels were limited to $5-20 \%$ of the diet there was no depression in growth. The crude protein of the diets with the sweet potato peels was about $31 \%$, within the required protein levels for juvenile herbivorous fish.

Sweet potato peels have also attracted attention for containing considerable quantities of phenolic compounds which are reported to have as much as three times the antioxidant activity of other plant tissues. In their research on the extraction of phenolics from sweet potato peels, ANASTACIO \& CARVALHO (2013) reported that the solvent: solid ratio and the depth of peel-cut influenced the amount of phenolics produced. Total phenolic compounds range from 1.02-6.21 GAE (gallic acid equivalent)/g d.w., and the antioxidant activity determined by the ferricreducing antioxidant power was between 0.71-8.11 TE (trolox equivalent)/g d.w.

STEED \& TRUONG (2008) also found that the peels of sweet potato contained almost three times as much total phenolics as the flesh and whole root. They reported about $1483.7 \mathrm{mg}$ CAE (caffeic acid equivalent) $100 \mathrm{~g}^{-1}$ in raw peels and $1298.1 \mathrm{mg}$ CAE $100 \mathrm{~g}^{-1}$ in steamed peels while the total phenolic content of the whole root was only $469.9 \mathrm{mg}$ CAE $100 \mathrm{~g}^{-1}$ raw. For processes that produce a lot of peels as byproducts, extraction of phenolic compounds would be a good way of decreasing the amount of waste while producing a value-added product with economic impact.

Soluble fiber is an important nutritional supplement that could be produced from sweet potato peels. The production of low cost soluble fiber from sweet potatoes could provide a new source of inexpensive dietary fiber. The process of micronizing the sweet potato peels resulted in a higher proportion of soluble to insoluble fiber compared with untreated peels while rendering a more useful, nutritional product for human consumption (HUANG et al., 2010a).

Sweet potato peels have been successfully fermented with lactic acid bacteria such as Lactobacillus rhamnosus to produce lactic acid. PAGANA et al. (2014) were able to produce $10 \mathrm{~g}$ of lactic acid per liter of sweet potato waste. This is
$40 \%$ of the theoretical yield based on $30 \mathrm{~g}$ of glucose available in the sweet potato waste media. Although lactic acid has conventionally been produced from corn, it makes ecological and economic sense to produce it from organic materials which would otherwise be wasted.

Anaerobic digestion of sweet potato food waste can be used to produce biogas. GE et al. (2014) compared methane production of tropical forestry (albizia) wastes with food wastes including sweet potato, taro, and papaya and found that although the highest volumetric production came from the albizia waste, the highest yield came from food wastes, including the sweet potato.

With increasing consumer demand, the food processing sector is gradually replacing artificial coloring with natural pigments that are sourced from fruits, flowers and vegetables. One of the distinguishing characteristics of different cultivars of sweet potato is the pigmentation in the flesh and the peel. This pigmentation is due to the presence of anthocyanins and carotenoids which produce the purple, orange and yellow coloring seen in tubers. The purple sweet potatoes are noted to have higher anthocyanin content than the other colors, and there have been studies into extracting the pigments from the tubers (LIU et al., 2013). While the major research is utilizing the tuber for extracting the pigments, the colored peels of the sweet potato are equally good sources of the compounds. Studies have shown that the anthocyanins are more concentrated in the peels than the flesh or whole tubers. Peels of purple-fleshed sweet potatoes generally contained higher anthocyanins than the flesh and could be a potential source for extracting the compounds (ZHU et al., 2010). Steed also noticed that the peels of sweet potato contained nearly two times as much anthocyanin in the flesh with about $174 \mathrm{mg} \mathrm{ml}^{-1}$ f.w. (STEED \& TRUONG, 2008).

Potential uses of wastewater from sweet potato starch production

Wastewater from sweet potato starch production can significantly pollute surrounding water systems because it is replete with nutrients and has a high chemical oxygen demand (COD) and biochemical oxygen demand (BOD). About $6 \mathrm{~m}^{3}$ of wastewater is generated for every ton of sweet potato roots processed. In order for starch production to be environmentally sustainable, the wastewater from its production must be utilized in a way that removes nutrients and COD. Waste water from sweet potato starch processing with a COD of about $1900 \mathrm{mg} \mathrm{l}^{-1}$ and considerable amounts of nitrogen, phosphorus and other nutrients was a suitable medium for 
the cultivation of Paenibacillus polymyxa to be used as bio-fertilizer for tea plants (XU et al., 2014). The solid fraction that remains after starch extraction is rich in fiber, which can be recovered by a milling and sieving process to yield dietary fiber (TAKAMINE et al., 2000).

The residue from starch production can also be used for the production of antibiotics. Oxytetracycline has been produced by the fermentation of sweet potato starch with Streptomyces rimosus and tetracycline has been produced using Streptomyces viridifaciens (YANG \& LING, 1989).

The predominant storage protein in sweet potatoes is sporamin, making up about $80 \%$ of the total protein content (BOVELL-BENJAMIN, 2007). Protein from the waste stream from sweet potato starch production can be removed from this prodigious effluent by foam separation. This technique has been perfected at the industrial level, where optimization of such factors as $\mathrm{pH}$, influent protein content and volume, flowrate, and column angle are critical to the success of the process. When optimized, sweet potato protein recovery reaches $84.1 \%$, and reduces BOD and COD (MU et al., 2014).

Another use for the sweet potato residue produced as a byproduct of starch production is to ferment it to produce single cell protein. Fermentation utilizing a mixed culture of Fusarium moniliforme and Saccharomyces cerevisiae yielded nitrogen utilization of $95.81 \%$ vs $78.20 \%$ for the control when the substrate was pre-treated with $\mathrm{HCl}$ and gamma irradiation (AZIZ \& MOHSEN, 2002). The authors pointed out that the properties of the resulting protein made it useful not only as a food supplement but also as a food ingredient (YANG \& LING, 1989).

The residue from sweet potato starch production has also been used to generate hydrogen by culturing the residue with Clostridium butyricum and Enterobacter aerogenes (YOKOI et al., 2002). Amylolytic yeasts can raise the protein content of sweet potato residue from $6 \%$ to $21 \%$ within 3 days via solid state fermentation (YANG, 1988; YANG, 1993; YANG et al., 1993).

\section{Utilization of waste from alcoholic fermentations}

In Japan, sweet potato is fermented to produce an alcoholic beverage called shochu. In the Kyushu district of Japan, where about 91\% of Japan's single-distilled shochu is produced, about 509,000 tons of shochu waste was produced in 2002 (FEDERATION OF BREWER'S ASSOCIATION OF KAGOSHIMA PREFECTURE, 2003). One novel use for some of this waste is to manufacture fibrous paper pots which can be used to grow seedlings. The pots have the added benefit of fertilizing the seedlings as the pots disintegrate after transplantation into the ground (YAMAUCHI et al., 2006).

Wastewater from alcoholic distillation of sweet potatoes contains a significant amount of dissolved phosphorus, which leads to waterway eutrophication unless it is removed. The yeast Hansenula anomala, when grown with the shochu waste, effectively flocculates $70-80 \%$ of the dissolved phosphorus (WATANABE et al., 2009).

Biogas has also been produced by digesting the shochu distillation waste with a diverse microbial community including methanogens and bacteria from the phyla, Firmicutes and Bacteroidetes, in a fullscale, fixed-bed reactor (KOBAYASHI et al., 2014).

\section{CONCLUSION}

Sweet potato cultivation is widely distributed around the world and sweet potatoes are consumed mainly because of its carbohydrates. The industrial processing of sweet potatoes in products such as starch, flour, canned products, and purees generates an extraordinary amount of byproducts that have very little utilization at the moment. These byproducts are trims and peels that result from the raw material preparation step before further processing. In the best case scenario, these byproducts are fed to animals, but most commonly are landfilled or discharged in bodies of water.

An important volume of research has been conducted in the last few decades about the utilization of sweet potato processing byproducts, which indicates that sweet potato byproducts have the potential the recovery of functional proteins, phenolic compounds, soluble fiber, anthocyanins, and carotenoids. Due to its carbohydrate-rich nature, sweet potato byproducts could be used as a substrate for the production of ethanol and lactic acid or the production of biogas by anaerobic digestion.

Leaves and vines are rich in nutrients and have the potential to be used for human consumption after cooking. Also, leaves and vines contain important levels of polyphenols and carotenoids that could be recovered and used as antioxidants and colorants respectively.

\section{REFERENCES}

AN, L. V. et al. Ileal and total tract digestibility in growing pigs fed cassava root meal diets with inclusion of fresh, dry and ensiled sweet potato (Ipomoea batatas L. (Lam.)) leaves. Animal Feed Science and Technology, v.114, n.1-4, p.127-139, 2004. Available from: <http:// www.sciencedirect.com/science/article/pii/S0377840104000288>. Accessed: January 12, 2017. doi: 10.1016/j.anifeedsci.2003.12.007. 
ANASTACIO, A.; CARVALHO, I. S. Phenolics extraction from sweet potato peels: Key factors screening through a PlacketBurman design. Industrial Crops and Products, v.43, n.1, p.99-105, 2013. Available from: <http://www.sciencedirect.com/ science/article/pii/S0926669012003809>. Accessed: January 12, 2017. doi: 10.1016/j.indcrop.2012.07.011.

AREGHEORE, E. M. Nutritive value of sweet potato (Ipomea batatas (L) Lam) forage as goat feed: voluntary intake, growth and digestibility of mixed rations of sweet potato and batiki grass (Ischaemum aristatum var. indicum). Small Ruminant Research, v.51, n.3, p.235-241, 2004. Available from: <http:// www.sciencedirect.com/science/article/pii/S0921448803001986>. Accessed: January 12, 2017. doi: 10.1016/S0921-4488(03)00198-6.

AZIZ, N. H.; MOHSEN, G. I. Bioconversion of acid- and gammaray-treated sweet potato residue to microbial protein by mixed cultures. Journal of Industrial Microbiology \& Biotechnology, v.29, n.5, p.264-267, 2002. Available from: <https://www.ncbi. nlm.nih.gov/pubmed/12407461>. Accessed: January 12, 2017. doi: 10.1038/sj.jim. 7000297.

BHASKARACHARY, K. et al. Carotene content of some common and less familiar foods of plant origin. Food Chemistry, v.54, p.189-193, 1995. Available from: <http://www.sciencedirect.com/ science/article/pii/030881469500029I>. Accessed: January 12, 2017. doi: 10.1016/0308-8146(95)00029-I.

BOVELL-BENJAMIN, A. Sweet potato: a review of its past, present, and future role in human nutrition. Advances in Food and Nutrition Research, v.52, p.1-59, 2007. Available from: <http:// www.sciencedirect.com/science/article/pii/S1043452606520017>. Accessed: January 12, 2017. doi: 10.1016/S1043-4526(06)52001-7.

DONGMEZA, E. et al. Investigations on the nutrient and antinutrient content of typical plants used as fish feed in small scale aquaculture in the mountainous regions of Northern Vietnam. Animal Feed Science and Technology, v.149, n.1-2, p.162-178, 2009. Available from: <http://www.sciencedirect.com/science/ article/pii/S0377840108001466>. Accessed: January 12, 2017. doi: $10.1016 /$ j.anifeedsci.2008.04.012.

FAO. Statistical website. Online. Available from: $<$ http://faostat3. fao.org/home>. Accessed: Apr. 18, 2016.

FARRELL, D. J. et al. A note on a comparison of the feeding value of sweet potato vines and lucerne meal for broiler chickens. Animal Feed Science and Technology, v.85, n.1-2, p.145-150, 2000. Available from: <http://www.sciencedirect.com/science/ article/pii/S0377840100001188>. Accessed: January 12, 2017. doi: 10.1016/S0377-8401(00)00118-8.

FEDERATION OF BREWER'S ASSOCIATION OF KAGOSHIMA PREFECTURE. Amount of single-distilled shochu by raw material in 2003 brew year and amount of distillation lees by treatment and month. Japan: Federation of Brewer's Association of Kagoshima Prefecture, 2003. [In Japanese].

GE, X. et al. Biogas energy production from tropical biomass wastes by anaerobic digestion. Bioresource Technology, v.169, p.38-44, 2014. Available from: <http://www.sciencedirect.com/ science/article/pii/S0960852414009213>. Accessed: January 12, 2017. doi: 10.1016/j.biortech.2014.06.067.

HUANG, C. et al. Effects of micronization on the physicochemical properties of peels of three root and tuber crops. Journal of the Science of Food and Agriculture, v.90, n.5, p.759-763, 2010a. Available from: $<$ http://onlinelibrary.wiley.com/doi/10.1002/jsfa.3879/abstract $>$. Accessed: January 12, 2017. doi: 10.1002/jsfa.3879.

HUANG, M. et al. Inhibitory effects of sweet potato leaves on nitric oxide production and protein nitration. Food Chemistry, v.121, n.2, p.480-486, 2010b. Available from: <http://www.sciencedirect. com/science/article/pii/S0308814609014885>. Accessed: January 12, 2017. doi: 10.1016/j.foodchem.2009.12.068.

HUE, S. et al. Extraction from agricultural waste, Ipomoea batatas L. lam leaves as a cheap source of natural dye. International Journal of Environmental Bioremediation \& Biodegradation, v.2, n.1, p.1-4, 2014. Available from: <http://pubs.sciepub.com/ijebb/2/1/1>. Accessed: January 12, 2017. doi: 10.12691/ijebb-2-1-1.

ISHIDA, H. et al. Nutritive evaluation on chemical components of leaves, stalks and stems of sweet potatoes (Ipomoea batatas poir). Food Chemistry, v.68, n.3, p.359-367, 2000. Available from: <http:// www.sciencedirect.com/science/article/pii/S030881469900206X>. Accessed: January 12, 2017. doi: 10.1016/S0308-8146(99)00206-X.

ISHIGURO, K.; MAKOTO Y. Content of an eye-protective nutrient lutein in sweet potato leaves. Acta Horticulturae. V.703, p.253-256. Available from: <http://www.actahort.org/books/703/703_32.htm>. Accessed: January 12, 2017. doi: 10.17660/ActaHortic.2006.703.32.

ISLAM, M. et al. Growth inhibition of pathogenic bacterial by artificially grown Ipomoea batatas (L.) leaf (abstr.). HortScience, v.39, p.778, 2004. Available from: <http://hortsci.ashspublications. org/content/39/4/778.2>. Accessed: January 12, 2017.

ISLAM, M. S.; JALALUDDDIN, M. Sweet potato: A potential nutritionally rich multifunctional food crop for Arkansas. Journal of Arkansas Agriculture and Rural Development, v.4, p.3-7, 2004.

ISLAM, M. et al. Anthocyanin compositions in sweet potato (Ipomoea batatas L.) leaves. Bioscience Biotechnology and Biochemistry, v.6, n.11, p.2483-2486, 2002. Available from: $<$ http://www.tandfonline.com/doi/abs/10.1271/bbb.66.2483>. Accessed: January 12, 2017. doi: 10.1271/bbb.66.2483.

KARIUKI, J. et al. Effect of feeding napier grass, lucerne and sweet potato vines as sole diets to dairy heifers on nutrient intake, weight gain and rumen degradation. Livestock Production Science, v. 55 , n.1, p.13-20, 1998. Available from: <http://www.sciencedirect. com/science/article/pii/S0301622698001274>. Accessed: January 12, 2017. doi: 10.1016/S0301-6226(98)00127-4.

KATONGOLE, C. et al. Intake, growth and carcass yield of indigenous goats fed market wastes of sweet potato (Ipomoea batatas) vines and scarlet eggplant (Solanum aethiopicum). Tropical Animal Health and Production, v.41, n.8, p.1623-1631, 2009. Available from: <http://link.springer.com/article/10.1007/s11250-009-9357-0>. Accessed: January 12, 2017. doi: 10.1007/s11250-009-9357-0.

KOBAYASHI, T. et al. Digestion performance and microbial community in full-scale methane fermentation of stillage from sweet potato-shochu production. Journal of Environmental SciencesChina, v.26, n.2, p.423-431, 2014. Available from: <http://www. sciencedirect.com/science/article/pii/S1001074213604234>. Accessed: January 12, 2017. doi: 10.1016/S1001-0742(13)60423-4.

LANDRUM, J. T.; BONE, R. A. Lutein, zeaxanthin, and the macular pigment. Archives of Biochemistry and Biophysics, v. 385, n.1, p.28-40, 2001. Available from: <http://www.sciencedirect. 
com/science/article/pii/S0003986100921714>. Accessed: January 12, 2017. doi: 10.1006/abbi.2000.2171

MALONEY, K. et al. Chemical optimization of protein extraction from sweet potato (Ipomoea batatas) peel. Journal of Food Science, v.77, n.11, p.E307-E312, 2012. Available from: <http://onlinelibrary. wiley.com/doi/10.1111/j.1750-3841.2012.02921.x/full>. Accessed: January 12, 2017. doi: 10.1111/j.1750-3841.2012.02921.x.

MENELAOU, E. et al. Lutein content in sweetpotato leaves HortScience, v.41, n.5, p.1269-1271, 2006. Available from: $<$ http://hortsci.ashspublications.org/content/41/5/1269.abstract $>$. Accessed: January 12, 2017.

MOSHA, T. C. et al. Effect of blanching on the content of antinutritional factors in selected vegetables. Plant Foods for Human Nutrition, v.47, n.4, p.361-367, 1995. Available from: $<$ http://link.springer.com/article/10.1007/BF01088275>. Accessed: January 12, 2017. doi: 10.1007/BF01088275.

MU, T. et al. Protein recovery from sweet potato starch wastewater by foam separation. Separation Science and Technology, v.49, n.14, p.2255-2260, 2014. Available from: $<$ http://www.tandfonline. com/doi/abs/10.1080/01496395.2014.911324>. Accessed: January 12, 2017. doi: 10.1080/01496395.2014.911324.

NGUYEN, T. et al. Ileal and total tract apparent crude protein and amino acid digestibility of ensiled and dried cassava leaves and sweet potato vines in growing pigs. Animal Feed Science and Technology, v.172, n.3-4, p.171-179, 2012. Available from: $<$ http:// www.sciencedirect.com/science/article/pii/S0377840111004858>. Accessed: January 12, 2017. doi: 10.1016/j.anifeedsci.2011.11.009.

OKE, M.; WORKNEH, T. A review on sweet potato postharvest processing and preservation technology. African Journal of Agricultural Research, v.8, n.40, p.4990-5003, 2013. Available from: <http:/www.academicjournals.org/journal/ AJAR/article-abstract/372C32641144>. Accessed: January 12 2017. doi: 10.5897/AJAR2013.6841.

OMOREGIE, E. et al. Effect of varying levels of sweet potato (Ipomea batatas) peels on growth, feed utilization and some biochemical responses of the cichlid (Oreochromis niloticus). African Journal of Food Agriculture Nutrition and Development, v.9, n.2, p.700-712, 2009. Available from: <http:// www.ajol.info/index.php/ajfand/article/view/19227>. Accessed: January 12, 2017. doi: 10.4314/ajfand.v9i2.19227.

PAGANA, I. et al. Lactic acid production using waste generated from sweet potato processing. International Journal of Food Science and Technology, v.49, n.2, p.641-649, 2014. Available from: <http:// onlinelibrary.wiley.com/doi/10.1111/ijfs.12347/abstract>. Accessed January 12, 2017. doi: 10.1111/ijfs. 12347

REGNIER, C. et al. Digestive utilization of tropical foliages of cassava, sweet potatoes, wild cocoyam and erythrina in Creole growing pigs. Animal Feed Science and Technology, v.180, n.14, p.44-54, 2013. Available from: <http://www.sciencedirect.com/ science/article/pii/S0377840113000023>. Accessed: January 12 2017. doi: 10.1016/j.anifeedsci.2012.12.007.

REGNIER, C. et al. Ileal digestibility of amino acids of cassava, sweet potato, cocoyam and erythrina foliages fed to growing pigs. Animal, v.6, n.4, p.586-593, 2012. Available from: <https://doi. org/10.1017/S1751731111001959>. Accessed: January 12, 2017. doi: $10.1017 / \mathrm{S} 1751731111001959$
SCHAUB, S.; LEONARD, J. Composting: an alternative waste management option for food processing industries. Trends in Food Science \& Technology, v.7, n.8, p.263-268, 1996. Available from: <http://www.sciencedirect.com/science/article/ pii/0924224496100297>. Accessed: January 12, 2017. doi: 10.1016/0924-2244(96)10029-7.

STEED, L.; TRUONG, V. Anthocyanin content, antioxidant activity, and selected physical properties of flowable purplefleshed sweetpotato purees. Journal of Food Science, v.73, n.5, p.S215-S221, 2008. Available from: <http://onlinelibrary.wiley.com/ doi/10.1111/j.1750-3841.2008.00774.x/full>. Accessed: January 12, 2017. doi: 10.1111/j.1750-3841.2008.00774.x.

SUN, H. et al. Sweet potato (Ipomoea batatas L.) leaves as nutritional and functional foods. Food Chemistry, v.156, p.380389, 2014. Available from: <http://www.sciencedirect.com/ science/article/pii/S0308814614001113>. Accessed: January 12, 2017. doi: 10.1016/j.foodchem.2014.01.079

TAKAMINE, K. et al. A new manufacturing process for dietary fiber from sweetpotato residue and its physical characteristics. Journal of Applied Glycoscience, v.47, n.1, p.67-72, 2000. Available from: $<$ https://www.jstage.jst.go.jp/article/jag 1999/47/1/47 1 67/ article $>$. Accessed: January 12, 2017. doi: 10.5458/jag.47.67.

TRUONG, V. et al. Phenolic acid content and composition in leaves and roots of common commercial sweetpotato (Ipomea batatas $L$.) cultivars in the United States. Journal of Food Science, v.72, n.6, p.C343-C349, 2007. Available from: <http://onlinelibrary.wiley. com/doi/10.1111/j.1750-3841.2007.00415.x/abstract $>$. Accessed: January 12, 2017. doi: 10.1111/j.1750-3841.2007.00415.x.

WALTER, W. et al. Sweet-potato protein - a review. Journal of Agricultural and Food Chemistry, v.32, n.4, p.695-699, 1984 Available from: $<$ http://pubs.acs.org/doi/abs/10.1021/jf00124a001 $>$. Accessed: January 12, 2017. doi: 10.1021/jf00124a001.

WATANABE, T. et al. Treatment and phosphorus removal from high-concentration organic wastewater by the yeast Hansenula anomala J224 PAWA. Bioresource Technology, v.100, n.5, p.1781-1785, 2009. Available from: <http://www.sciencedirect. com/science/article/pii/S0960852408008535>. Accessed: January 12, 2017. doi: 10.1016/j.biortech.2008.10.006

WOOLFE, J. Sweet potato: an untapped food resource. New York: Cambridge University, 1992. 660 pages. ISBN-13: 9780521050531 .

XU, S. et al. Bioconversion of wastewater from sweet potato starch production to Paenibacillus polymyxa biofertilizer for tea plants. Scientific Reports, v.4, n.4131, p.1-7, 2014.

YAMAUCHI, M. et al. Recycled pots using sweet potato distillation lees. Resources Conservation and Recycling, v.47, n.2, p.183-194, 2006. Available from: <http://www.nature.com/articles/srep04131>. Accessed: January 12, 2017. doi: 10.1038/srep04131.

YANG, S. Protein enrichment of sweet potato residue with coculture of amylolytic fungi by solid-state fermentation. Biotechnology Advances, v.11, n.3, p.495-505, 1993. Available from: $<$ http://link. springer.com/article/10.1007/BF00327851>. Accessed: January 12, 2017. doi: $10.1007 / \mathrm{BF} 00327851$

YANG, S. Protein enrichment of sweet potato residue with amylolytic yeasts by solid- state fermentation. Biotechnology 
and Bioengineering, v.32, n.7, p.886-890, 1988. Available from: $<$ http://onlinelibrary.wiley.com/doi/10.1002/bit.260320706/ abstract>. Accessed: January 12, 2017. doi: 10.1002/bit.260320706.

YANG, S.; LING, M. Tetracycline production with sweetpotato residue by solid-state fermentation. Biotechnology and Bioengineering, v.33, n.8, p.1021-1028, 1989. Available from: $<$ http://onlinelibrary.wiley.com/doi/10.1002/bit.260330811/full>. Accessed: January 12, 2017. doi: 10.1002/bit.260330811.

YANG, S. et al. Protein enrichment of sweet-potato residue by solidstate cultivation with mono-cultures and cocultures of amylolytic fungi. World Journal of Microbiology \& Biotechnology, v.9, n.2, p.258-264, 1993. Available from: <http://link.springer.com/
article/10.1007/BF00327851>. Accessed: January 12, 2017. doi: 10.1007/BF00327851.

YOKOI, H. et al. Microbial production of hydrogen from starchmanufacturing wastes. Biomass \& Bioenergy, v.22, n.5, p.389395, 2002. Available from: $<$ http://www.sciencedirect.com/science/ article/pii/S0961953402000144> . Accessed: January 12, 2017. doi: 10.1016/S0961-9534(02)00014-4.

ZHU, F. et al. Anthocyanins, hydroxycinnamic acid derivatives, and antioxidant activity in roots of different chinese purple-fleshed sweetpotato genotypes. Journal of Agricultural and Food Chemistry, v.58, n.13, p.7588-7596, 2010. Available from: $<$ http://pubs.acs.org/doi/abs/10.1021/ jf101867t $>$. Accessed: January 12, 2017. doi: 10.1021/jf101867t. 